\title{
Stereo- and regioselective construction of vicinal stereogenic quaternary carbon atoms: enantiospecific approach to cyperanes
}

\author{
Adusumilli Srikrishna* and Chikkana Dinesh \\ Department of Organic Chemistry, Indian Institute of Science, Bangalore 560 012, India
}

\begin{abstract}
An enantiospecific approach to a functionalised carbon framework of the sesquiterpenes, cyperanes, starting from the monoterpene $(R)$-carvone has been accomplished. A combination of a Claisen rearrangement, intramolecular diazo ketone cyclopropanation and regiospecific cyclopropane ring cleavage has been exploited for the stereo and regiospecific generation of the vicinal stereogenic quaternary carbon atoms.
\end{abstract}

\section{Introduction}

The dried tuberous roots or rhizome of Cyperus rotundus Linne, an officially listed traditional medicine in Chinese pharmacopoeia, are used in the treatment of illnesses connected with child birth or menstrual disorder. In Vietnam and Japan, it is often used for treating stomach ache, irregular menstruation, dysentery, nausea and gynecological diseases. In Malaysia, it is used to cure pain in the nose by inhaling smoke from the burning drug, while in Indonesia, it is used as a stimulant and stomachic. In India, it is used as diuretic and for irregular menstruation, fever, disorder in digestive tract and various haematological diseases. The essential oil, as well as the solvent extracts of the rhizomes of $C$. rotun- dus LinNe have been subjected to numerous studies resulting in the isolation of many terpenoids. ${ }^{1}$ Hikino et al. $^{2}$ have reported the isolation of sesquiterpene cyperolone 1, containing the 1-ethyl-3-isopropyl-6methylbi- cyclo[4.3.0]nonane 2 (cyperane) carbon framework, from the tuber of nutgrass $C$. rotundus LiNNE of Japanese origin. Dev et al. ${ }^{4}$ have reported the isolation of cyperolone 1 from the same oil of Indian origin. Results obtained from chemical studies on cyperus plants showed that cyperolone $\mathbf{1}$ and other chemical constituents of $C$. rotundus LinNe are responsible for plant growth inhibitory activities, antimicrobial activities and insect repellent activities. ${ }^{5}$ Subsequently, the isolation of sesquiterpenes 3-8, which have the cyperane carbon framework, were reported (Chart 1). ${ }^{6}$

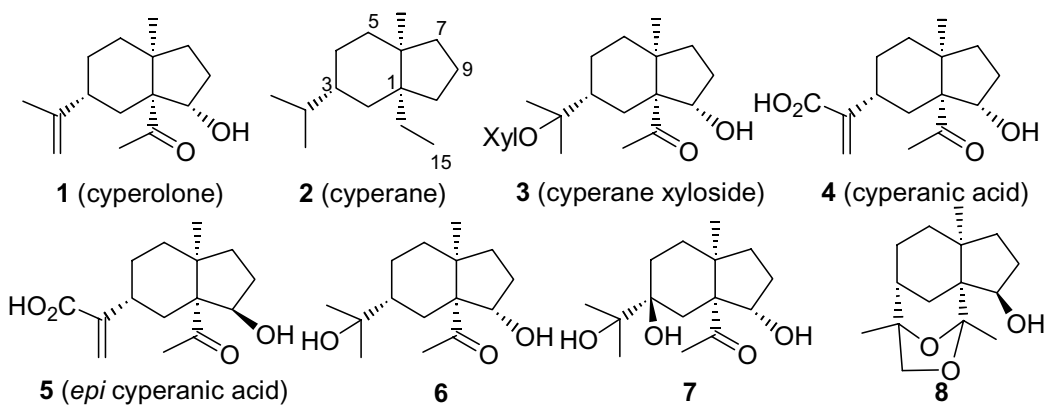

Chart 1.

\footnotetext{
* Corresponding author. Tel.: +91 80 22932215; fax: +91 80 23600683; e-mail: ask@orgchem.iisc.ernet.in
} 
The presence of a bicyclo[4.3.0]nonane carbon framework incorporating two stereogenic quaternary carbon atoms at the ring junction positions and three to four stereogenic centres make cyperanes attractive synthetic targets. Despite the known biological properties, very little effort has been directed towards the synthesis of cyperanes. Hikino et al. ${ }^{3}$ reported the first synthesis of cyperolone 1 by employing a pinacol-pinacolone rearrangement as the key step. Subsequently, research groups of $\mathrm{Dev}^{7}$ and Hikino ${ }^{8}$ reported the rearrangement of epoxy-eudesmanes to generate cyperane and epicyperanes. Ceccherelli et al. ${ }^{9}$ reported the synthesis of an analogue of cyperanic acid. Herein, we report an enantioselective approach to the functionalised carbon framework of cyperanes starting from the readily and abundantly available monoterpene $(R)$-carvone 9, employing a combination of Claisen rearrangementintramolecular diazo ketone cyclopropanation-regioselective cyclopropane ring cleavage for the construction of the vicinal stereogenic quaternary carbon atoms.

\section{Results and discussion}

Initially the synthesis of a 3-epi-cyperane was investigated. It was anticipated that intramolecular cycloprop- anation of diazo ketone $\mathbf{1 0}$ derived from acid $\mathbf{1 1}$ would generate tricyclic ketone 12, which could be transformed into 3-epi-cyperane $\mathbf{1 3}$ via reductive cyclopropane ring cleavage (Scheme 1). Acid 11, being a $\gamma, \delta$-unsaturated carbonyl system, could be obtained via a stereoselective Claisen rearrangement of allyl alcohol 14, which could be obtained from carvone 9 via 3-ethylcarvone $\mathbf{1 5}$.

The sequence was started with the conversion of $(R)$ carvone 9 into $(S)$-3-ethylcarvone 15, employing a 1,3alkylative enone transposition strategy (Scheme 2). ${ }^{10}$ Thus, a sonochemically accelerated Barbier reaction of carvone 9 with ethyl bromide and lithium in THF furnished the tertiary alcohol 16, which on oxidation with PCC and silica gel, generated $(S)$-3-ethylcarvone $\mathbf{1 5}$ in $70 \%$ yield. Reduction of 3-ethylcarvone 15 with $\mathrm{LAH}$ in ether at $-70{ }^{\circ} \mathrm{C}$ gave allyl alcohol 14 in a highly regioand stereoselective manner. ${ }^{11}$ The orthoester Claisen rearrangement ${ }^{12}$ of the allyl alcohol 14 with triethyl orthoacetate and a catalytic amount of propionic acid in a sealed tube at $180^{\circ} \mathrm{C}$ generated ester 17, which on hydrolysis with sodium hydroxide in refluxing aqueous methanol furnished acid 11. Reaction of acid $\mathbf{1 1}$ with oxalyl chloride, followed by treatment of the resultant acid chloride with an excess of ethereal diazomethane generated diazo ketone 10. Copper and anhydrous

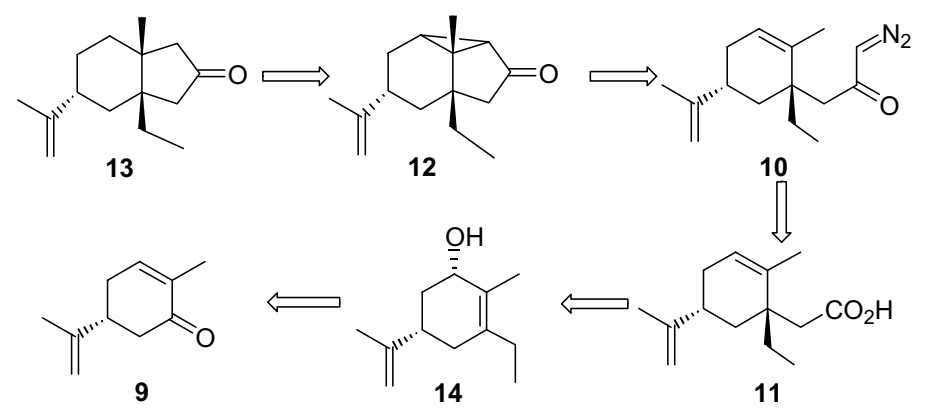

Scheme 1.

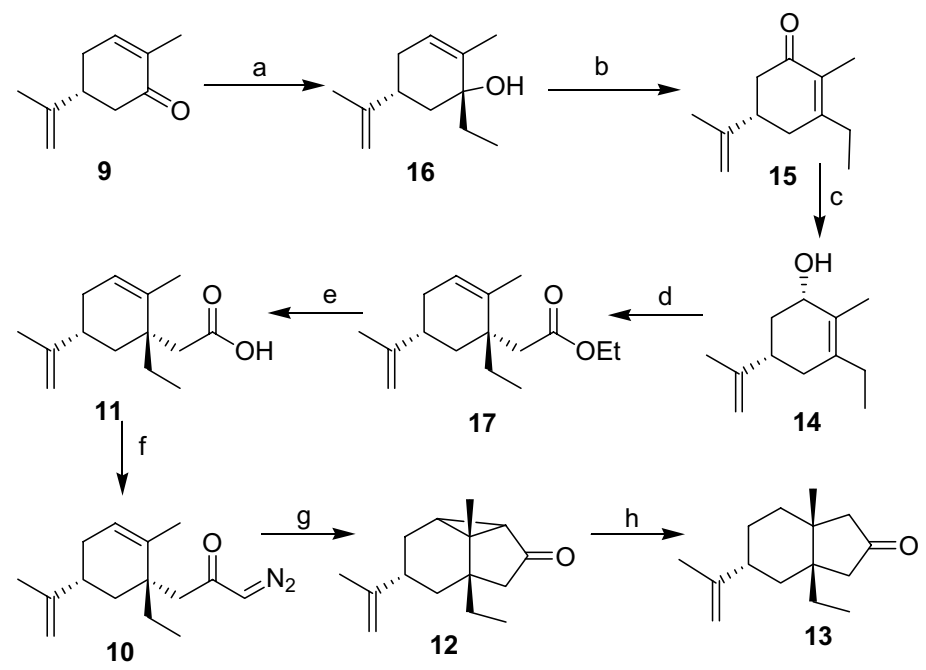

Scheme 2. Reagents, conditions and yields: (a) EtBr, Li, ))), THF, 40 min, rt; (b) PCC, silica gel, $\mathrm{CH}_{2} \mathrm{Cl}_{2}, 6 \mathrm{~h}$; $70 \%$ for two steps; (c) LAH, Et ${ }_{2} \mathrm{O}$, $-70{ }^{\circ} \mathrm{C}, 95 \%$; (d) $\mathrm{MeC}(\mathrm{OEt})_{3}, \mathrm{EtCOOH}, 180{ }^{\circ} \mathrm{C}, 96 \mathrm{~h}, 61 \%$; (e) $5 \% \mathrm{NaOH}, \mathrm{H}_{2} \mathrm{O}-\mathrm{MeOH}$, reflux, $7 \mathrm{~h}, 95 \%$; (f) $\left(\mathrm{COCl}_{2}, \mathrm{C}_{6} \mathrm{H}_{6}, \mathrm{rt}_{2} 2 \mathrm{~h} ; \mathrm{CH}_{2} \mathrm{~N}_{2}, \mathrm{Et}_{2} \mathrm{O}\right.$, rt, $2 \mathrm{~h} ;(\mathrm{g}) \mathrm{Cu}, \mathrm{CuSO}_{4}, c-\mathrm{C}_{6} \mathrm{H}_{12}$, W-lamp, $5 \mathrm{~h}, 57 \%$ from acid 11; (h) Li, liq. $\mathrm{NH}_{3}, \mathrm{THF}, 76 \%$. 
copper sulfate catalysed decomposition of diazo ketone $\mathbf{1 0}$ in refluxing cyclohexane, irradiated by a tungsten lamp, led to the intramolecular insertion of the intermediate keto-carbenoid into the olefin ring in a regioand stereoselective manner, ${ }^{13}$ resulting in the formation of tricyclic ketone 12, whose structure was established from its spectral data. It was readily identified that regioselective cleavage of the $\mathrm{C}_{2}-\mathrm{C}_{9}$ cyclopropane bond in 12 transforms it into an epi-cyperane. Accordingly, treatment of tricyclic ketone $\mathbf{1 2}$ with lithium in liquid ammonia furnished bicylic ketone ${ }^{17} 13$ via regiospecific cyclopropane ring cleavage. ${ }^{14}$

Next, attention was turned towards the synthesis of an epi-cyperane having functionality at $\mathrm{C}-15$ position. Phenyl group was considered as a masked carboxylic acid group. It was envisaged that substitution of a benzyl group in the place of the ethyl group would be a suitable choice, and the sequence was carried out via 3-benzylcarvone 18 (Scheme 3). Thus, sonochemically accelerated Barbier reaction of carvone 9 with benzyl bromide and lithium in THF at $0{ }^{\circ} \mathrm{C}$, followed by oxidation of the resultant tertiary alcohol 19 with a mixture of PCC and silica gel in methylene chloride at room temperature furnished enone $\mathbf{1 8}$ in $63 \%$ yield. Regio- and stereoselective reduction of enone $\mathbf{1 8}$ with $\mathrm{LAH}$ in ether at low temperature $\left(-70^{\circ} \mathrm{C}\right)$ furnished allyl alcohol 20 . The orthoester Claisen rearrangement of allyl alcohol 20 with triethyl orthoacetate and a catalytic amount of propionic acid in a sealed tube at $180^{\circ} \mathrm{C}$, generated ester 21 in a stereoselective manner, which on hydrolysis with sodium hydroxide in refluxing aqueous methanol, furnished acid 22. Acid $\mathbf{2 2}$ was converted into the diazo ketone 23 via the corresponding acid chloride. Copper and anhydrous copper sulfate catalysed decomposition of the diazo ketone $\mathbf{2 3}$ in refluxing cyclohexane, irradiated by a tungsten lamp, led to the intramolecular insertion of the intermediate keto-carbenoid into the ring olefin, resulting in the formation of the tricyclic ketone $\mathbf{2 4}$. Regioselective cyclopropane ring cleavage of tricyclic ketone 24 using lithium in liquid ammonia furnished bicyclic ketone 25. Attention was then turned towards the oxidative degradation ${ }^{15}$ of the phenyl group. Hydrogenation of the isopropenyl moiety in $\mathbf{2 5}$ using $10 \%$ palladium on carbon as the catalyst under $1 \mathrm{~atm}$ of hydrogen in ethanol furnished the bicyclic ketone $\mathbf{2 6}$. Reaction of the bicyclic ketone $\mathbf{2 6}$ with a catalytic amount of ruthenium chloride and sodium periodate in a 1:1:1 mixture of acetonitrile, water and carbon tetrachloride furnished the keto acid $\mathbf{2 7}$, which on esterification with an excess of diazomethane in ether, generated the keto ester $\mathbf{2 8}{ }^{18}$

After successfully accomplishing the synthesis of $\mathbf{1 3}$ and 28, attention was focussed on the synthesis of a cyperane. For the synthesis of a cyperane, it was obvious that the isopropyl group needed to be syn to the ring junction substituents. Since the stereochemistry of the ring junction positions were derived from the stereochemistry of the hydroxy group in the allyl alcohol $\mathbf{2 0}$, inversion of the stereochemistry of the hydroxy group in allyl alcohol 20 would change the stereochemistry of the ring junction substituents syn to the isopropenyl group; hence a Mitsunobu reaction ${ }^{16}$ was chosen (Scheme 4). Consequently, the reaction of allyl alcohol 20 with triphenylphosphine and diethyl azo-dicarboxylate (DEAD) in the presence of benzoic acid in THF, generated benzoate $\mathbf{2 9}$ in $63 \%$ yield. Hydrolysis of the benzoate group in $\mathbf{2 9}$ using potassium carbonate in methanol, furnished the anti-alcohol 30. The structure of alcohol $\mathbf{3 0}$ was deduced from its spectral data in comparison with that of the syn-alcohol 20. The orthoester Claisen rearrangement of the allyl alcohol $\mathbf{3 0}$ with triethyl orthoacetate and a catalytic amount of propionic

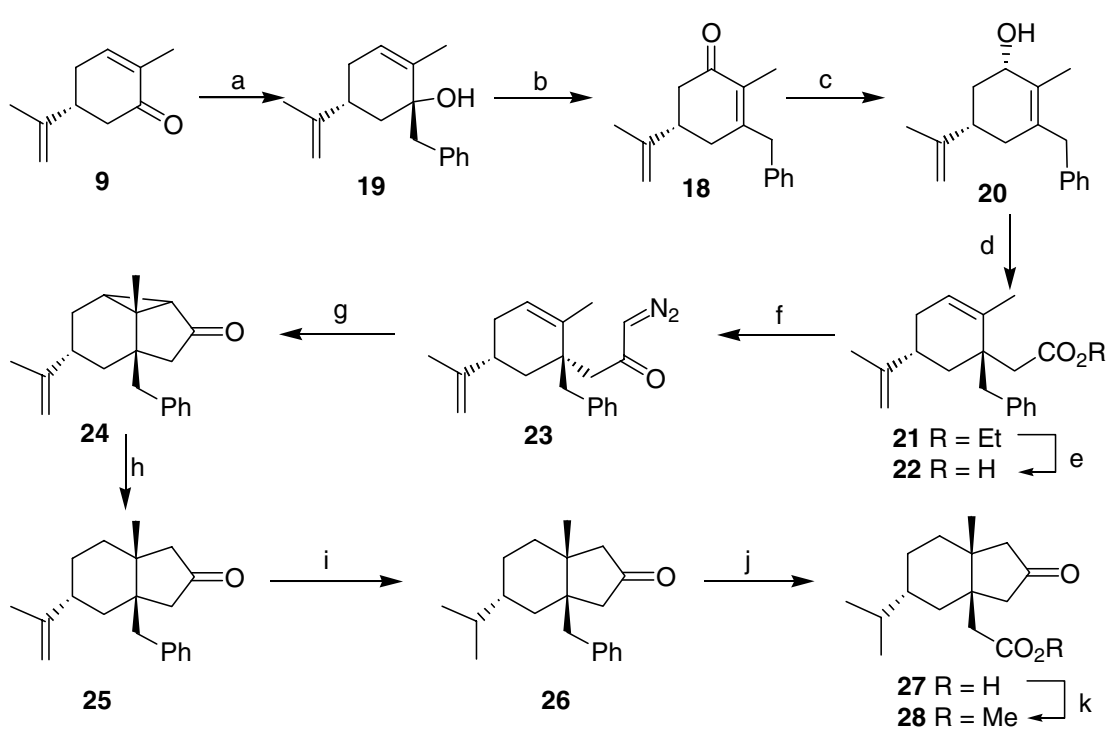

Scheme 3. Reagents, conditions and yields: (a) $\mathrm{PhCH}_{2} \mathrm{Br}$, Li, ))), THF, $0{ }^{\circ} \mathrm{C} \rightarrow \mathrm{rt}, 1 \mathrm{~h}$; (b) PCC, silica gel, $\mathrm{CH}_{2} \mathrm{Cl}_{2}, 8 \mathrm{~h}$; $63 \%$ for two steps; (c) $\mathrm{LAH}$, $\mathrm{Et}_{2} \mathrm{O},-70^{\circ} \mathrm{C}, 90 \%$; (d) $\mathrm{MeC}(\mathrm{OEt})_{3}, \mathrm{EtCOOH}, 180{ }^{\circ} \mathrm{C}, 96 \mathrm{~h}, 58 \%$; (e) $5 \% \mathrm{NaOH}, \mathrm{H}_{2} \mathrm{O}-\mathrm{MeOH}$, reflux, $7 \mathrm{~h}, 98 \%$; (f) $\left(\mathrm{COCl}_{2}, \mathrm{C}_{6} \mathrm{H}_{6}, \mathrm{rt}_{2}, 2 \mathrm{~h} ; \mathrm{CH}_{2} \mathrm{~N}_{2}\right.$, $\mathrm{Et}_{2} \mathrm{O}, \mathrm{rt}, 2 \mathrm{~h}$; (g) $\mathrm{Cu}, \mathrm{CuSO}_{4}, c-\mathrm{C}_{6} \mathrm{H}_{12}$, W-lamp, $5 \mathrm{~h}, 63 \%$ from acid 22; (h) Li, liq. $\mathrm{NH}_{3}, \mathrm{THF}, 83 \%$; (i) $10 \% \mathrm{Pd} / \mathrm{C}, \mathrm{EtOH}, \mathrm{H}_{2}, 6 \mathrm{~h}, 99 \%$; (j) $\mathrm{RuCl}_{3} \cdot x \mathrm{H}_{2} \mathrm{O}, \mathrm{CCl}_{4}, \mathrm{H}_{2} \mathrm{O}, \mathrm{MeCN}, \mathrm{rt}, 8 \mathrm{~h}, 57 \%$; (k) $\mathrm{CH}_{2} \mathrm{~N}_{2}, \mathrm{Et}_{2} \mathrm{O}, 0{ }^{\circ} \mathrm{C}, 2 \mathrm{~h}, 90 \%$. 


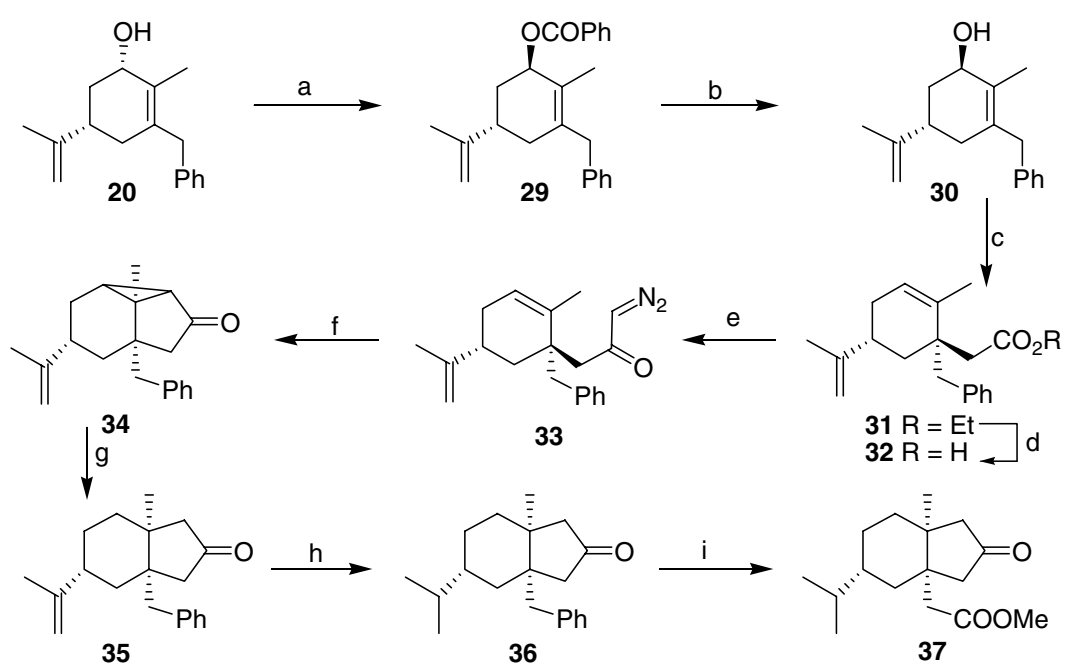

Scheme 4. Reagents, conditions and yields: (a) $\mathrm{PPh}_{3}, \mathrm{DEAD}, \mathrm{PhCOOH}, \mathrm{THF}, \mathrm{rt}, 24 \mathrm{~h}, 63 \%$; (b) $\mathrm{K}_{2} \mathrm{CO} 3, \mathrm{MeOH}, \mathrm{rt}, 10 \mathrm{~h}, 84 \%$; (c) $\mathrm{MeC}(\mathrm{OEt})_{3}$, EtCOOH, $180{ }^{\circ} \mathrm{C}, 72 \mathrm{~h}, 61 \%$; (d) $5 \% \mathrm{NaOH}, \mathrm{H}_{2} \mathrm{O}-\mathrm{MeOH}$, reflux, $7 \mathrm{~h}, 92 \%$; (e) $\left(\mathrm{COCl}_{2}, \mathrm{C}_{6} \mathrm{H}_{6}, \mathrm{rt}, 2\right.$ h, $\mathrm{CH}_{2} \mathrm{~N}_{2}, \mathrm{Et}_{2} \mathrm{O}, \mathrm{rt}, 2 \mathrm{~h} ;$ (f) $\mathrm{Cu}, \mathrm{CuSO}$, c- $\mathrm{C}_{6} \mathrm{H}_{12}$, W-lamp, 6 h, 55\% from acid 32; (g) Li, liq. $\mathrm{NH}_{3}, \mathrm{THF}, 80 \%$; (h) $10 \% \mathrm{Pd} / \mathrm{C}, \mathrm{EtOH}, \mathrm{H}_{2}, 6 \mathrm{~h}, 99 \%$; (i) $\mathrm{RuCl}_{3} \cdot x \mathrm{H}_{2} \mathrm{O}, \mathrm{CCl}_{4}, \mathrm{H}_{2} \mathrm{O}, \mathrm{MeCN} \mathrm{rt}, 8 \mathrm{~h} ; \mathrm{CH}_{2} \mathrm{~N}_{2}$, $\mathrm{Et}_{2} \mathrm{O}, 0{ }^{\circ} \mathrm{C}, 2 \mathrm{~h}, 55 \%$.

acid in a sealed tube at $180^{\circ} \mathrm{C}$, followed by hydrolysis of the resultant ester $\mathbf{3 1}$ with sodium hydroxide in refluxing aqueous methanol, furnished acid $\mathbf{3 2}$. Acid $\mathbf{3 2}$ was then transformed into diazo ketone 33, which on treatment with copper and anhydrous copper sulfate in refluxing cyclohexane, irradiated by a tungsten lamp, led to the formation of tricyclic ketone 34. Regioselective cyclopropane ring cleavage of tricyclic ketone 34 using lithium under liquid ammonia conditions furnished bicyclic ketone 35, which on hydrogenation using $10 \%$ palladium on carbon as the catalyst in ethanol at $1 \mathrm{~atm}$ of hydrogen furnished bicyclic ketone 36. Oxidative degradation of the phenyl group in the bicyclic ketone $\mathbf{3 6}$ with a catalytic amount of ruthenium chloride and sodium periodate in a 1:1:1 mixture of acetonitrile, water and carbon tetrachloride followed by esterification with diazomethane in ether furnished ester 37. ${ }^{19}$

\section{Conclusion}

In conclusion, we have developed a convenient short enantioselective approach for the construction of the complete carbon framework of cyperane sesquiterpenes. A sequence comprising of a Claisen rearrangement, intramolecular diazo ketone cyclopropanation and regioselective cyclopropane ring cleavage reaction has been exploited for the construction of the two vicinal stereogenic quaternary carbon atoms. The strategy herein is general and suitable for the synthesis of several analogues of cyperanes to assess their biological potential, which is currently under investigation.

\section{Acknowledgements}

We thank the Council of Scientific and Industrial Research, New Delhi for the award of a research fellowship to C.D.

\section{References}

1. Sonwa, M. M.; Konig, W. A. Phytochemistry 2001, 58, 799.

2. Hikino, H.; Aota, K.; Maebayashi, Y.; Takemoto, T. Chem. Pharm. Bull. 1966, 14, 1439.

3. Hikino, H.; Aota, K.; Norio, S.; Takemoto, T. Chem. Pharm. Bull. 1966, 14, 1441.

4. Kapadia, V. H.; Naik, V. G.; Wadia, M. S.; Dev, S. Tetrahedron Lett. 1967, 4661.

5. Komai, K.; Seto, N.; Matsubayashi, K.; Hamada, M. Zasso Kenkyu 1990, 35, 64.

6. El-Ghazouly, M. G.; El-Sebakhy, N. A.; El-Din, A. A. S.; Zdero, C.; Bohlmann, F. Phytochemistry 1987, 26, 439; Ceccherelli, P.; Curini, M.; Marcotullio, M. C. J. Nat. Prod. 1988, 51, 1006; Ceccherelli, P.; Curini, M.; Marcotulio, M. C.; Menghini, A. Phytochemistry 1985, 2987; Ahmed, A. A.; Jakupovic, J. Phytochemistry 1990, 29, 3658; Todorova, M. N.; Tsankova, E. T. Phytochemistry 1999, 52, 1515; Ohira, S.; Hasegawa, T.; Hayashi, K.-i.; Hoshino, T.; Takaoka, D.; Nozaki, H. Phytochemistry 1998, 48, 1577.

7. Mehta, G.; Chetty, G. L.; Nayak, U. R.; Dev, S. Tetrahedron 1968, 24, 3775.

8. Hikino, H.; Kohama, T.; Takemoto, T. Tetrahedron 1969, $25,1037$.

9. Ceccherelli, P.; Curini, M.; Marcotullio, M. C.; Rosati, O. Tetrahedron 1989, 45, 3809.

10. (a) Buchi, G.; Egger, B. J. Org. Chem. 1971, 36, 2021; (b) Srikrishna, A.; Hemamalini, P. Indian J. Chem. 1990, 29B, 479.

11. Garver, L.; van Eikeren, P.; Byrd, J. E. J. Org. Chem. 1976, 41, 2773.

12. Johnson, W. S.; Werthemann, L.; Bartlett, W. R.; Brocksom, T. J.; Li, T. T.; Faulkner, D. J.; Petersen, M. R. J. Am. Chem. Soc. 1970, 92, 741.

13. (a) Stork, G.; Ficini, J. J. Am. Chem. Soc. 1961, 83, 4678; (b) Burke, S. D.; Grieco, P. A. Org. React. 1979, 26, 361; (c) Mander, L. N. Synlett 1991, 134.

14. (a) Norin, T. Acta Chem. Scand. 1963, 17, 738; (b) Dauben, W. G.; Deviny, E. J. J. Org. Chem. 1966, 31, 3794; (c) Dauben, W. G.; Wolf, R. E. J. Org. Chem. 1970, 35, 374; (d) Dauben, W. G.; Wolf, R. E. J. Org. Chem. 1970, 35, 2361; (e) Norin, T. Acta Chem. Scand. 1965, 19, 1289. 
15. Nunez, M. T.; Martin, V. S. J. Org. Chem. 1990, 55, 1928. 16. (a) Mitsunobu, O. Synthesis 1981, 1; (b) Hughes, D. L. Org. React. 1992, 42, 335.

17. All the compounds exhibited spectral data (IR, ${ }^{1} \mathrm{H}$ and ${ }^{13} \mathrm{C}$ NMR and mass) consistent with their structures. Selected spectral data for 13: $[\alpha]_{\mathrm{D}}^{28}=-47.5\left(c\right.$ 1.2, $\left.\mathrm{CHCl}_{3}\right)$. IR (neat): $\quad v_{\max } / \mathrm{cm}^{-1} 1742, \quad 887 .{ }^{1} \mathrm{H} \quad \mathrm{NMR} \quad(300 \mathrm{MHz}$, $\left.\mathrm{CDCl}_{3}+\mathrm{CCl}_{4}\right): \delta 4.67(2 \mathrm{H}, \mathrm{s}), 2.69(1 \mathrm{H}, \mathrm{d}, J 18.6 \mathrm{~Hz})$, $2.20(1 \mathrm{H}, \mathrm{d}, J 18.3 \mathrm{~Hz}), 1.98(1 \mathrm{H}, \mathrm{d}, J 18.3 \mathrm{~Hz}), 1.75-1.20$ $(10 \mathrm{H}, \mathrm{m}), 1.72(3 \mathrm{H}, \mathrm{s}), 0.98(3 \mathrm{H}, \mathrm{s}), 0.85(3 \mathrm{H}, \mathrm{t}, J 7.5 \mathrm{~Hz})$. ${ }^{13} \mathrm{C}$ NMR $\left(75 \mathrm{MHz}, \mathrm{CDCl}_{3}+\mathrm{CCl}_{4}\right): \delta 217.6(\mathrm{C}), 149.3$ (C), $109.0\left(\mathrm{CH}_{2}\right), 50.4\left(\mathrm{CH}_{2}\right), 48.5\left(\mathrm{CH}_{2}\right), 43.8(\mathrm{C}), 40.8$ (C), $40.0(\mathrm{CH}), 35.3\left(\mathrm{CH}_{2}\right), 32.7\left(\mathrm{CH}_{2}\right), 27.0\left(\mathrm{CH}_{2}\right), 25.4$ $\left(\mathrm{CH}_{3}\right), 24.3\left(\mathrm{CH}_{2}\right), 21.1\left(\mathrm{CH}_{3}\right), 9.6\left(\mathrm{CH}_{3}\right)$.

18. For 28: $[\alpha]_{\mathrm{D}}^{23}=-40.0\left(c 0.5, \mathrm{CHCl}_{3}\right)$. IR (neat): $v_{\max } / \mathrm{cm}^{-1}$ 1739. ${ }^{1} \mathrm{H} \mathrm{NMR}\left(300 \mathrm{MHz}, \mathrm{CDCl}_{3}+\mathrm{CCl}_{4}\right): \delta 3.65(3 \mathrm{H}, \mathrm{s})$, $2.67(1 \mathrm{H}, \mathrm{d}, J 13.5 \mathrm{~Hz}), 2.60(1 \mathrm{H}, \mathrm{d}, J 18.9 \mathrm{~Hz}), 2.52(1 \mathrm{H}$, d, $J 19.2 \mathrm{~Hz}), 2.33(1 \mathrm{H}, \mathrm{d}, J 13.5 \mathrm{~Hz}), 2.20(1 \mathrm{H}, \mathrm{d}, J$ $18.9 \mathrm{~Hz}), 1.75(1 \mathrm{H}, \mathrm{d}, J 19.2 \mathrm{~Hz}), 1.70-1.00(7 \mathrm{H}, \mathrm{m}), 1.05-$ $1.00(1 \mathrm{H}, \mathrm{m}), 0.98(3 \mathrm{H}, \mathrm{s}), 0.86(3 \mathrm{H}, \mathrm{d}, J 6.6 \mathrm{~Hz}), 0.84(3 \mathrm{H}$, d, $J 6.6 \mathrm{~Hz}) .{ }^{13} \mathrm{C} \mathrm{NMR}\left(75 \mathrm{MHz}, \mathrm{CDCl}_{3}+\mathrm{CCl}_{4}\right): \delta 217.1$ (C), $172.5(\mathrm{C}), 51.4\left(\mathrm{CH}_{3}\right), 51.3\left(\mathrm{CH}_{2}\right), 47.6\left(\mathrm{CH}_{2}\right), 42.6$ (C), $41.0(\mathrm{C}), 39.0(\mathrm{CH}), 38.0\left(\mathrm{CH}_{2}\right), 35.6\left(\mathrm{CH}_{2}\right), 32.6$ $\left(\mathrm{CH}_{2}\right), 32.5(\mathrm{CH}), 25.6\left(\mathrm{CH}_{3}\right), 25.2\left(\mathrm{CH}_{2}\right), 19.9\left(\mathrm{CH}_{3}\right)$, $19.6\left(\mathrm{CH}_{3}\right)$

19. For 37: $[\alpha]_{\mathrm{D}}^{23}=-57.0\left(c 1.0, \mathrm{CHCl}_{3}\right)$. IR (neat): $v_{\max } / \mathrm{cm}^{-1}$ 1739. ${ }^{1} \mathrm{H}$ NMR $\left(300 \mathrm{MHz}, \mathrm{CDCl}_{3}+\mathrm{CCl}_{4}\right): \delta 3.65(3 \mathrm{H}, \mathrm{s})$, $2.40-2.00(3 \mathrm{H}, \mathrm{m}), 1.90(1 \mathrm{H}, \mathrm{d}, J 18.0 \mathrm{~Hz}), 1.75-1.00$ $(10 \mathrm{H}, \mathrm{m}), 1.11(3 \mathrm{H}, \mathrm{s}), 0.90(3 \mathrm{H}, \mathrm{d}, J 6.6 \mathrm{~Hz}), 0.89(3 \mathrm{H}, \mathrm{d}$, $J 6.6 \mathrm{~Hz}) \cdot{ }^{13} \mathrm{C} \mathrm{NMR}\left(75 \mathrm{MHz}, \mathrm{CDCl}_{3}+\mathrm{CCl}_{4}\right): \delta 215.9$ (C), $171.8(\mathrm{C}), 52.5\left(\mathrm{CH}_{2}\right), 51.2\left(\mathrm{CH}_{3}\right), 44.4\left(\mathrm{CH}_{2}\right), 43.9$ (C), $41.9\left(\mathrm{CH}_{2}\right), 40.2(\mathrm{C}), 38.6(\mathrm{CH}), 37.4\left(\mathrm{CH}_{2}\right)$, $33.4\left(\mathrm{CH}_{2}\right), 32.5(\mathrm{CH}), 24.7\left(\mathrm{CH}_{2}\right), 20.1\left(\mathrm{CH}_{3}\right), 19.5(2 \mathrm{C}$, $\mathrm{CH}_{3}$ ). 